\title{
Growth and flowering performance evaluation of thirty two chrysanthemum cultivars
}

\author{
A. F. M. Jamal Uddin ${ }^{a}$, T. Taufique ${ }^{a}$, A. F. Ona ${ }^{a}$, S. Shahrin ${ }^{a}$ and H. Mehraj $^{b}$ \\ apept. of Horticulture, Sher-e-Bangla Agricultural University, Dhaka-1207, Bangladesh \\ ${ }^{b}$ The United Graduate School of Agricultural Sciences, Ehime University, 3-5-7 Tarami, Matsumaya, Ehime \\ 790-8556, Japan
}

\begin{abstract}
An experiment was conducted to evaluate the growth and flowering performance of chrysanthemum cultivars. Thirty two chrysanthemum cultivars coded from $V_{1}$ to $V_{32}$ were used in the experiment. Plant height, number of branch per plant, leaf area, number of leaf per branch, chlorophyll content, days to flower bud initiation, days to first petal spread, days to final bloom, number of flower bud per plant, number of flower per branch, number of flower per plant, bud diameter at initiation stage, bud diameter at mature stage, flower head diameter, stalk length and flower durability in plant (days to $50 \%$ flower senescence) for different cultivars varied significantly. Number of flowers per plant ranged from 4.3 to 194.6, flower head diameters varied from 2.8 to $17.6 \mathrm{~cm}$ and stalk lengths were from 4.4 to $20.1 \mathrm{~cm}$. Amongst the chrysanthemum cultivars $V_{15}$ (BARI chrysanthenum1) was the maximum flower producing cultivar, while $V_{1}$ produced the largest flowers and flowers from the $V_{21}$ had the longest shelf-life. These variations might help in classifying chrysanthemum, for pot cultivation and cut flower, based on their flowering quality which will be beneficial for growers.
\end{abstract}

Keywords: Chrysanthemum sp., Growth and flower characteristics, species variation

Please cite this article as: Jamal Uddin, A. F. M., Taufique, T., Ona, A. F., Shahrin, S. and Mehraj, H. (2015). Growth and flowering performance evaluation of thirty two chrysanthemum cultivars. Journal of Bioscience and Agriculture Research 04(01): 40-51.

This article is distributed under terms of a Creative Common Attribution 4.0 International License

\section{Introduction}

Chrysanthemum (Chrysanthemum sp.) belonging to Asteraceae family is a highly attractive and charming flowering plant, having number of varieties in the world is reported to be above 2000 (Joshi et al., 2010). Chrysanthemums are used either as cut flowers or grown in pots and the success in cultivation of this plant is principally due to the great diversity of cultivars (Barbosa, 2003). Though the flower yield and quality are primarily varietals characters, they are also greatly influenced by climatic factors. A numerous number of chrysanthemum cultivars are found in Bangladesh. BARI has developed only two chrysanthemum cultivars (BARI, 2011) and rest of the cultivars were brought in by commercial growers from different countries without scientific information. The growth and flowering performance of these cultivars have not been evaluated. Most of the growers do not have overall idea about all of these cultivars. Varietal performance evaluation can be helpful for the 
commercial chrysanthemum grower to choose their preferable one. For searching the good variety/cultivars, varietal performance has previously evaluated on different crops like rose (Shahrin et al., 2015), gerbera (Hossain et al., 2015; Mehraj et al., 2014b; Jamal Uddin et al., 2014b), dendrobium (Mehraj et al., 2014d), bougainvillea (Mehraj et al., 2014e), heliconia (Islam et al., 2013a), anthurium (Islam et al., 2013), lisianthus (Jamal Uddin et al., 2013), strawberry (Ahsan et al., 2014; Hossan et al., 2013); tomato (Nahiyan et al., 2014; Biswas et al., 2014; Mehraj et al., 2014c), chilli (Chowdhury et al., 2015; Mehraj et al., 2014a), asparagus (Jamal Uddin et al., 2014a) and all of these crops showed variations in their performances. It is essential for plant breeders to estimate the type of variation available in the cultivars for easy selection for further breeding of respective crops. The study was conducted to evaluate the performance of the cultivars in respect to their different traits.

\section{Materials and Methods}

Experimental site: The experiment was conducted at Horticulture Farm of the Sher-e-Bangla Agricultural University, Dhaka, from October 2012 to March 2013.

Planting materials: Growing chrysanthemum plants from a sucker is, the easiest and quickest way to propagate. Suckers of chrysanthemum were collected from the Horticulture farm, Sher-e-Bangla Agricultural University, Dhaka; Krishibid Upokorn Nursery, Agargaon, Dhaka and Barishal Nursery, Savar, Dhaka; Bngladesh. New plant was generated by planting sucker from mother chrysanthemum.

Design of experiment: 32 chrysanthemum cultivars were used. They were Crimson Tide $\left(\mathrm{V}_{1}\right)$; Samsan $\left(\mathrm{V}_{2}\right)$; White Snowball $\left(\mathrm{V}_{3}\right)$; Chandramukhi $\left(\mathrm{V}_{4}\right)$; Lexy $\left(\mathrm{V}_{5}\right)$; Rose Pink $\left(\mathrm{V}_{6}\right)$; Yellow Glow $\left(\mathrm{V}_{7}\right)$; Ruby Red $\left(\mathrm{V}_{8}\right)$; Gold Apricot $\left(\mathrm{V}_{9}\right)$; Sunny Yellow $\left(\mathrm{V}_{10}\right)$; Lavender Mum $\left(\mathrm{V}_{11}\right)$; Giant Bronze $\left(\mathrm{V}_{12}\right)$; Purple Mum $\left(\mathrm{V}_{13}\right)$; Moon Ball $\left(\mathrm{V}_{14}\right)$; Yellow Bay $\left(\mathrm{V}_{15}\right)$; Pink Shasta Daisy $\left(\mathrm{V}_{16}\right)$; Bernadette Yellow $\left(\mathrm{V}_{17}\right)$; Mammoth Yellow $\left(\mathrm{V}_{18}\right)$; Auburn Daisy $\left(\mathrm{V}_{19}\right)$; Sweet Vase $\left(\mathrm{V}_{20}\right)$; First Light $\left(\mathrm{V}_{21}\right)$; Flying Saucer $\left(\mathrm{V}_{22}\right)$; Zipsy $\left(\mathrm{V}_{23}\right)$; Gold Mundial $\left(\mathrm{V}_{24}\right)$; Red Wing $\left(\mathrm{V}_{25}\right)$; Trendy Time $\left(\mathrm{V}_{26}\right)$; Rising Sun $\left(\mathrm{V}_{27}\right)$; BARI chrysanthemum $2\left(\mathrm{~V}_{28}\right)$; Rayonnate spider $\left(\mathrm{V}_{29}\right)$; Flair spider $\left(\mathrm{V}_{30}\right)$; Wisp of Red $\left(\mathrm{V}_{31}\right)$ and Satin Ribbon $\left(V_{32}\right)$. One sucker was planted in each pot and the size of each pot was $25 \mathrm{~cm}$ in diameter (above part) and $20 \mathrm{~cm}$ in height. Experiment was laid out in Completely Randomized Design (CRD) with three replications for each cultivar thus comprised to a total of 96 pots.

Pot preparation: Soil (approx. $2.5 \mathrm{~kg} / \mathrm{pot}$ ) and cow dung (approx. $1.5 \mathrm{~kg} /$ pot) were mixed and pots were filled 7 days before transplanting. Weeds and stubbles were completely removed

Disease and pest management: During the early growing stage powdery mildew and leaf spot were controlled by spraying Dithane M-45. Fungicide was sprayed two times at 15 days interval. Crop was also attacked by aphids during the growing stage. Aphid was controlled by spraying Malathion @ 1.5 $\mathrm{ml} / \mathrm{L}$. Insecticides were sprayed two times at seven days interval.

Data collection: Data were collected on plant height; number of branch, leaf area, number of leaf per branch, chlorophyll content, days to flower bud initiation, days to first petal spread, days to final bloom, number of flower bud per plant, number of flower per branch, number of flower per plant, bud diameter at initiation stage, bud diameter at mature stage, flower head diameter, stalk length and flower durability in plant (days to $50 \%$ flower senescence). Leaf area, chlorophyll content and flower bud diameter were measured by using CL-202 Leaf Area Meter (USA), SPAD-502 and Digital Caliper515 (DC-515) respectively. Ten mature leaves and bud from each plant were measured and then average it after that mean was calculated. Flower bud diameter at initiation stage and fully mature stage that are about to open in the next day. The total length from base of the branch to terminal node of flower was taken as stalk length. Flower durability in plant was measured by counting the duration of time in days that flower remains good condition in plant.

Statistical analysis: Data were analyzed using MSTAT-C statistical package and significant difference among the treatment means was determined by the Least Significant Difference (LSD) test at 5\% level of significance (Gomez and Gomez, 1984). In addition, error bar represents the standard error at 5\% level of significance. 


\section{Results and Discussion}

Plant height: Plant height of chrysanthemum exposed statistically significant variation among 32 cultivars at 30, 40 and 50 days after transplanting (DAT) (Figure 01). The range of plant height was from $71.8 \mathrm{~cm}$ to $23.7 \mathrm{~cm}$. The tallest plant was found from $V_{13}(71.8 \mathrm{~cm})$ whereas the shortest from $V_{8}$ $(23.7 \mathrm{~cm})$ at 50 DAT of chrysanthemum cultivars (Table 01). Present study referred that $\mathrm{V}_{13}$ (Sunny Yellow) exposed as the tallest plant among the cultivars at mature stage. Kim et al. (2014) found a range of 19.3-64.6 cm plant height in 15 Taxa of Korean chrysanthemum species and Ara et al. (20122013) found a range of $36-70 \mathrm{~cm}$. While Chandragiri et al. (2004) recorded maximum $132.16 \mathrm{~cm}$ plant height from Solomon Impala variety of chrysanthemum. Some cultivars of chrysanthemum were vigorous in growth and some were less vigorous, this might be caused by varietal characters responsible by a gene. As a genetically controlled factor, plant height varied among the cultivars of chrysanthemum (Kanamadi and Patil, 1993; Barigidad and Patil, 1992 and Baskaran et al., 2010). Similar variation in plant height among varieties was also observed in marigold (Raghuvanshi et al., 2011) and in rose (Hussain and Khan, 2004). The higher plant height obtained from plants could be attributed to increased photosynthetic capacity of the plants in asters (Vrsek et al., 2006).

Number of branches: 32 cultivars showed statistically significant difference at 30, 40 and 50 DAT (Figure 02) for number of branches per plant. Maximum number of branch was recorded from V6 (19.7/plant) while minimum from V2 (2.5/plant) at 50 DAT of chrysanthemum cultivars (Table 02). $\mathrm{V}_{7}$ cultivar (Yellow Glow) performed best in case number of branches per plant. Chaugule (1985) recorded a maximum 16.56 branches in chrysanthemum. Barigidad and Patil (1992) recorded a range of 2.75 to 18.58 branches in case of chrysanthemum cultivar. Difference in branches among the chrysanthemum cultivars could be due to influence of genetical make up of chrysanthemum cultivars (Hicklenton, 1985; Moe, 1988; Chezhian et al., 1985 and Kanamadi and Patil, 1993). Similar variation for number of branches was also observed in China aster (Munikrishnappa et al., 2013).

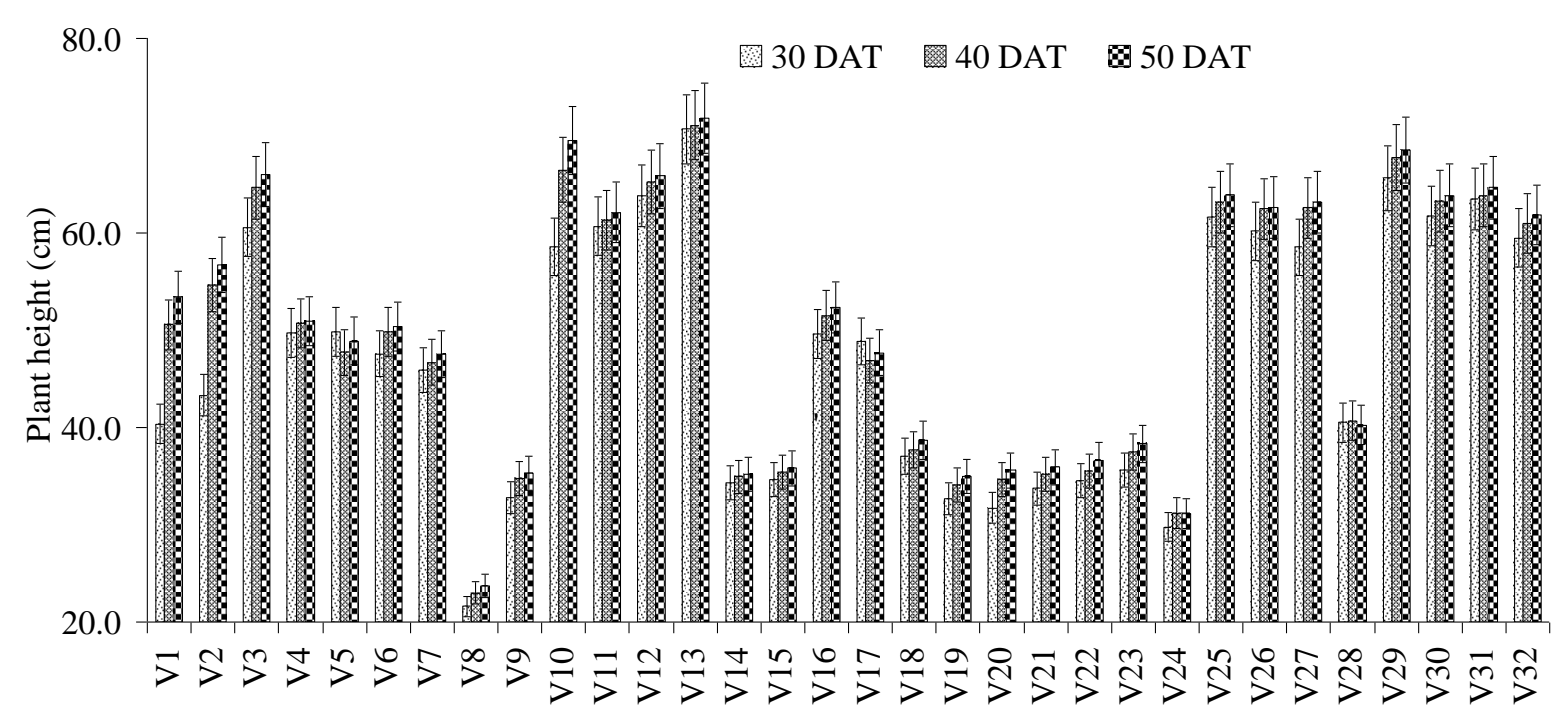

Chrysanthemum cultivars

Figure 01. Performance of 32 chrysanthemum cultivars for plant height at different days after transplanting

Number of leaves: Chrysanthemum cultivars showed significant variation for number of leaves per $20 \mathrm{~cm}$ branch. Maximum number of leaves was observed from $V_{11}(13.3 / 20 \mathrm{~cm}$ branch) and minimum from $V_{14}$ and $V_{24}\left(4.5 / 20 \mathrm{~cm}\right.$ branch) (Table 01). The result referred that $V_{11}$ (Lavender Mum) produced maximum number of leaves per branch $(20 \mathrm{~cm})$. Similar result on number of leaves was observed by Barigidad and Patil (1992) in chrysanthemum. Variation in number of leaves was previously reported by Wilfret et al. (1973). This difference for number of leaf per branch among cultivars was due to their genetic composition (Charles, 1995). 


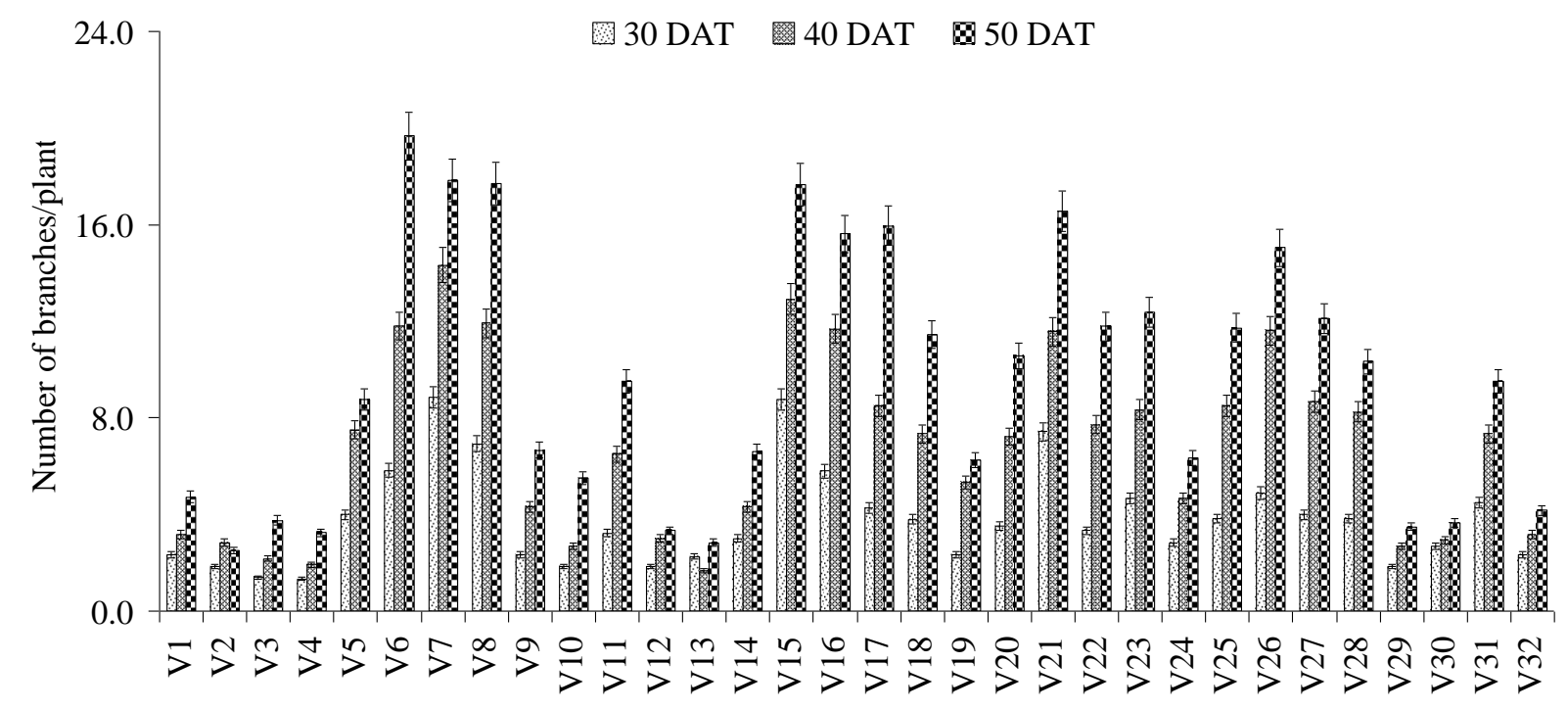

Chrysanthemum cultivars

\section{Figure 2. Performance of 32 chrysanthemum cultivars for number of branches per plant at different days after transplanting}

Leaf area: Leaf area showed significant variation among chrysanthemum cultivars. Maximum leaf area was found from $V_{1}\left(52.9 \mathrm{~cm}^{2}\right)$ whereas minimum from $V_{29}\left(5.9 \mathrm{~cm}^{2}\right)$ which scored lowest after flowering (Table 01). Results showed that $\mathrm{V}_{1}$ (Crimson Tide) provided maximum leaf area. Mitra and Paul (2008) recorded $47.2 \mathrm{~cm}^{2}$ leaf areas in un-pinched single stem cultivar of chrysanthemum. Greater leaf area may lead to more dry matter accumulation, which resulted in the accumulation of maximum photosynthates that contributed to produce bigger sized flower or more number of flowers. Similar variation in leaf area among cultivars was found in carnation (Gharge et al., 2009; Shiragur et al., 2004). Variation in leaf area indicates additive gene effects would be effective in gerbera (Nair and Shiva, 2003), dahlia (Vikas et al., 2011) and in chrysanthemum (Barigidad and Patil, 1992). Leaf area was found to be positively related with flower yield in carnation (Mahesh et al., 1996).

Chlorophyll content: Chlorophyll content varied significantly among chrysanthemum cultivars. Maximum chlorophyll content was obtained from $V_{10}(59.0 \%)$ and lowest was obtained from $V_{29}(23.9$ $\%)$ at mature stage (Table 01). This finding referred that $\mathrm{V}_{10}$ (Sunny Yellow) produced maximum chlorophyll percentage. Similar findings were obtained in wheat by Hamblin et al. (2014). This variation in chlorophyll percentage might be attributed to genetically differences. This variation might be due to the varietals characters as reported by (Thomas and Lekharani, 2008) in orchid. Chlorophyll content in leaf enhanced photosynthetic activity, which produce carbohydrates. Carbohydrates serve as energy source for growing bud, flower opening and longevity. The ultimate effect of all these factors resulted into strong and long flower stalks, large sized buds or flower (Tarannum, 2014).

Table 01. Performance of 32 chrysanthemum cultivars on plant height, number of branch, number of leaf per $20 \mathrm{~cm}$ branch, leaf area and chlorophyll content ${ }^{Y}$

\begin{tabular}{|c|c|c|c|c|c|c|c|c|c|c|}
\hline \multirow{3}{*}{$\begin{array}{c}\text { Variety }^{\mathrm{x}} \\
\mathrm{V}_{1}\end{array}$} & \multicolumn{4}{|c|}{ at $50 \mathrm{DAT}$} & \multirow{2}{*}{\multicolumn{2}{|c|}{$\begin{array}{l}\text { No. of leaf/branch } \\
\qquad(20 \mathrm{~cm})\end{array}$}} & \multirow{2}{*}{\multicolumn{2}{|c|}{$\begin{array}{l}\text { Leaf area } \\
\left(\mathrm{cm}^{2}\right)\end{array}$}} & \multirow{2}{*}{\multicolumn{2}{|c|}{$\begin{array}{l}\text { Chlorophyll } \\
\text { content (\%) }\end{array}$}} \\
\hline & \multicolumn{2}{|c|}{$\begin{array}{l}\text { Plant height } \\
(\mathrm{cm})\end{array}$} & \multicolumn{2}{|c|}{$\begin{array}{c}\text { Number of } \\
\text { branch/plant }\end{array}$} & & & & & & \\
\hline & 53.4 & $\mathrm{~h}$ & 4.7 & $\mathrm{~m}$ & 6.3 & ghijk & 52.9 & a & 48.7 & l \\
\hline $\mathrm{V}_{2}$ & 56.8 & g & 2.5 & $\mathrm{q}$ & 5.8 & ijklm & 50.0 & $\mathrm{~b}$ & 47.8 & $\mathrm{n}$ \\
\hline $\mathrm{V}_{3}$ & 66.0 & $\mathrm{c}$ & 3.8 & no & 5.3 & Imno & 23.8 & gh & 52.2 & gh \\
\hline $\mathrm{V}_{4}$ & 50.9 & $\mathrm{ij}$ & 3.3 & op & 5.6 & klmno & 42.2 & c & 49.0 & l \\
\hline$V_{5}$ & 48.9 & $\mathrm{kl}$ & 8.8 & j & 6.9 & efg & 20.9 & l & 41.8 & $q$ \\
\hline $\mathrm{V}_{6}$ & 50.4 & $\mathrm{jk}$ & 19.7 & a & 9.4 & c & 10.8 & $\mathrm{r}$ & 48.5 & $\operatorname{lm}$ \\
\hline
\end{tabular}




\begin{tabular}{|c|c|c|c|c|c|c|c|c|c|c|}
\hline$V_{7}$ & 47.6 & l & 17.8 & b & 9.5 & c & 35.8 & e & 55.9 & c \\
\hline$V_{8}$ & 23.7 & $r$ & 17.7 & $\mathrm{~b}$ & 10.4 & $\mathrm{~b}$ & 15.9 & $q$ & 53.7 & ef \\
\hline $\mathrm{V}_{9}$ & 35.3 & op & 6.7 & $\mathrm{k}$ & 6.5 & ghij & 31.2 & $\mathrm{f}$ & 57.7 & $\mathrm{~b}$ \\
\hline$V_{10}$ & 69.5 & $\mathrm{~b}$ & 5.5 & 1 & 4.8 & op & 18.6 & $\mathrm{~m}$ & 59.0 & $\mathrm{a}$ \\
\hline $\mathrm{V}_{11}$ & 62.1 & $\mathrm{f}$ & 9.5 & $\mathrm{i}$ & 13.3 & $\mathrm{a}$ & 20.8 & l & 45.6 & o \\
\hline$V_{12}$ & 65.9 & C & 3.3 & op & 6.3 & ghijk & 20.6 & 1 & 50.5 & j \\
\hline$V_{13}$ & 71.8 & $\mathrm{a}$ & 2.8 & $\mathrm{pq}$ & 6.5 & ghij & 49.7 & $b$ & 50.3 & $\mathrm{jk}$ \\
\hline$V_{14}$ & 35.2 & op & 6.6 & $\mathrm{k}$ & 4.5 & $\mathrm{p}$ & 18.0 & $\mathrm{mn}$ & 50.6 & $\mathrm{j}$ \\
\hline$V_{15}$ & 35.8 & op & 17.7 & $\mathrm{~b}$ & 12.8 & $\mathrm{a}$ & 15.8 & $\mathrm{q}$ & 49.7 & $\mathrm{k}$ \\
\hline$V_{16}$ & 52.3 & hi & 15.6 & de & 5.7 & jklmn & 22.2 & $\mathrm{k}$ & 43.0 & $\mathrm{p}$ \\
\hline$V_{17}$ & 47.7 & l & 16.0 & $\mathrm{~cd}$ & 7.4 & $\mathrm{de}$ & 17.2 & op & 40.4 & $\mathrm{r}$ \\
\hline $\mathrm{V}_{18}$ & 38.7 & $\mathrm{n}$ & 11.5 & $\mathrm{~g}$ & 7.7 & $\mathrm{~d}$ & 17.6 & no & 51.6 & hi \\
\hline$V_{19}$ & 35.0 & $\mathrm{p}$ & 6.2 & $\mathrm{k}$ & 6.7 & efgh & 7.3 & $\mathrm{~s}$ & 30.3 & $\mathrm{t}$ \\
\hline$V_{20}$ & 35.6 & op & 10.6 & $\mathrm{~h}$ & 6.5 & ghij & 7.2 & st & 31.0 & s \\
\hline $\mathrm{V}_{21}$ & 36.0 & op & 16.6 & c & 6.0 & hijkl & 6.5 & tu & 28.7 & $\mathrm{u}$ \\
\hline $\mathrm{V}_{22}$ & 36.6 & o & 11.8 & $\mathrm{fg}$ & 8.8 & c & 24.2 & g & 55.0 & $\mathrm{~d}$ \\
\hline $\mathrm{V}_{23}$ & 38.3 & $\mathrm{n}$ & 12.4 & f & 6.6 & fghi & 15.6 & $\mathrm{q}$ & 54.4 & de \\
\hline $\mathrm{V}_{24}$ & 31.1 & $\mathrm{q}$ & 6.3 & $\mathrm{k}$ & 4.5 & $\mathrm{p}$ & 7.4 & $\mathrm{~S}$ & 28.6 & $\mathrm{u}$ \\
\hline $\mathrm{V}_{25}$ & 63.9 & de & 11.7 & fg & 7.5 & de & 39.4 & $\mathrm{~d}$ & 50.9 & $\mathrm{ij}$ \\
\hline$V_{26}$ & 62.6 & ef & 15.0 & e & 6.3 & ghijk & 16.7 & $\mathrm{p}$ & 47.8 & $\mathrm{mn}$ \\
\hline $\mathrm{V}_{27}$ & 63.2 & def & 12.1 & fg & 5.7 & jklmn & 22.4 & $\mathrm{jk}$ & 53.5 & $\mathrm{f}$ \\
\hline$V_{28}$ & 40.3 & $\mathrm{~m}$ & 10.3 & h & 5.9 & ijkl & 23.1 & hi & 57.0 & $\mathrm{~b}$ \\
\hline$V_{29}$ & 68.5 & $\mathrm{~b}$ & 3.5 & nop & 5.8 & ijklm & 5.9 & $\mathrm{u}$ & 23.9 & $\mathrm{v}$ \\
\hline$V_{30}$ & 63.9 & de & 3.7 & no & 5.1 & mnop & 23.0 & $\mathrm{ij}$ & 52.5 & g \\
\hline$V_{31}$ & 64.7 & $\mathrm{~cd}$ & 9.5 & $\mathrm{i}$ & 5.0 & nop & 23.2 & hi & 52.4 & $\mathrm{~g}$ \\
\hline$V_{32}$ & 61.9 & $\mathrm{f}$ & 4.2 & $\mathrm{mn}$ & 7.3 & def & 23.9 & $\mathrm{~g}$ & 51.8 & gh \\
\hline CV\% & 0.6 & & 4.4 & & 7.0 & & 1.9 & & 0.9 & \\
\hline$L S D_{(0.05)}$ & 1.5 & & 0.7 & & 0.8 & & 0.7 & & 0.7 & \\
\hline
\end{tabular}

xChrysanthemum cultivars; YIn a column means having similar letter (s) are statistically identical and those having dissimilar letter (s) differ significantly as per 0.05 level of probability

Days to flower bud initiation: Significant variation was found (visual observation) among 32 chrysanthemum cultivars for the number of days to the emergence of flower bud (from days after transplantation of chrysanthemum suckers). Late flower bud initiation was found in $V_{9}$ (52.7 days) while earlier in $V_{3}$ (17.8 days) (Table 02). This findings referred that $V_{3}$ (White Snowball) was early flower bud initiating cultivar. Difference in number of days for flower bud initiation, number of days for flowering among different cultivars might be due to presence of sufficient genetic variability. Similar findings were obtained in Dahlia by Mishra and Saini (1997).

Days to first petal spread: Significant variation was found among the chrysanthemum cultivars in respect of days taken to first petal spread (from days after transplantation of chrysanthemum suckers). The shortest period was required for first petal spread in $V_{3}$ (39.5 days) while the longest period in $V_{4}$ (71.6 days) (Table 02). The result showed that $V_{3}$ cultivar (Sweet Vase) required minimum days for first petal spreading. Chrysanthemum required maximum 74.2 days for flower initiation (Wilfret, 1973) and minimum 31.25 days for first flower initiation (Joshi et al., 2010). This difference was due to genetical makeup of the cultivars. Similar variation was found in chrysanthemum (Baskaran et al., 2010) and China aster (Zosiamliana et al., 2012).

Days to final bloom: Significant difference was found among the chrysanthemum cultivars for the days taken from planting to final bloom. The shortest period was required for final bloom in $\mathrm{V}_{6}(52.8$ days) while the longest period in $\mathrm{V}_{4}$ (77.5 days) which was statistically identical with $\mathrm{V}_{10}$ (77.3 days) , $\mathrm{V}_{1}$ (77.2 days), $\mathrm{V}_{9}$ (76.7 days) and $\mathrm{V}_{30}$ (76.7 days) (Table 02). The result showed that $\mathrm{V}_{6}$ (Rose Pink) was early blooming cultivar. Flowering period was ranged from 50.59 to 132.99 days in chrysanthemum (Barigidad and Patil, 1996), which resulted late and early flowering habits among cultivars Flowering times in chrysanthemum are affected by varietal characters, habitat and species type (Kim et al., 2014 and Rajashekaran et al., 1985). 
Number of flower bud: Significant difference was observed for cumulative number of flower buds per plant in chrysanthemum cultivars at 30, 40 and 50 DAT (Figure 03). Maximum cumulative number of flower bud was found from $V_{15}$ (199.0/plant) whereas minimum was found from $V_{2}$ (4.3/plant) at 50 DAT of chrysanthemum cultivars (Table 02). $\mathrm{V}_{15}$ cultivar (Yellow Bay) showed the best result in case of number of flower bud per plant.

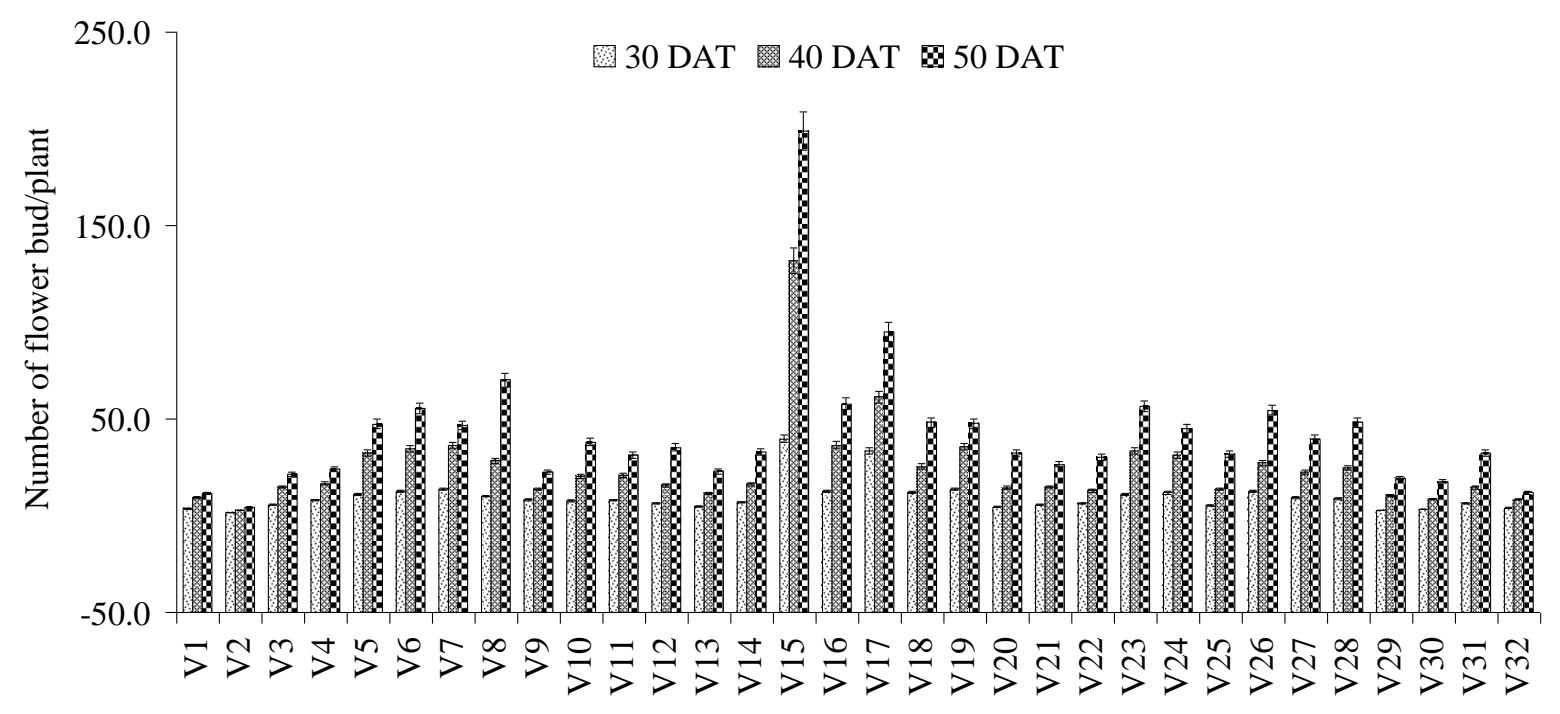

Chrysanthemum cultivars

Figure 3. Performance of 32 chrysanthemum cultivars for number of flower bud per
plant at different days after transplanting

Number of flower: Significant variation was found among the chrysanthemum cultivars in case of number of flower per branch. Maximum number of flower was found in $V_{15}(9.4 / 20 \mathrm{~cm}$ branch) while minimum from $V_{1}, V_{2}, V_{10}, V_{21}, V_{24}, V_{30}$ and $V_{31},(1.0 / 20 \mathrm{~cm}$ branch) (Table 02). This findings referred that $\mathrm{V}_{15}$ (Yellow Bay) produced maximum number of flower per branch. Numbers of maximum potential flowers per lateral branches were recorded, ranged from 6 to 8 (Wilfret et al., 1973). The highest number of flowers/branch (10.43) was produced by genotype White Anemone followed by Gauri (9.08) and Appu (7.66) (Punetha et al., 2011). Variation in number of flowers per plant is related to recurrent blooming habit due to their genetic makeup (Nadeem et al., 2011). Variation in flower yield was also observed previously in China aster (Negi and Raghava, 1985), in chrysanthemum (Chezhian et al., 1985) and marigold (Howe and Waters, 1991).

Number of flower: Significant variation was recorded among chrysanthemum cultivars performance in respect to the number of flower per plant. Maximum number of flower was found from $V_{15}$ (194.6/plant) whereas minimum was recorded form $V_{2}$ (4.3/plant) (Table 02). The result showed that $\mathrm{V}_{15}$ (Yellow Bay) performed as maximum flower producing cultivar. Chrysanthemum flower number was ranged from 25.0 to 100.0/plant (Wilfret et al., 1973) and 66.0 to 301.0 /plant (Punetha et al., 2011). Cultivar Button Type Local recorded the highest number of flowers per plant (287.00), whereas cv. Cass recorded the lowest (37.00) (Baskaran et al., 2010). In an experiment Ara et al. (2012-13) recorded maximum 70 flowers per plant in Chrysanthemum. Variation in number of flowers per plant was also observed previously in chrysanthemum (Chezhian et al., 1985) and in gerbera (Mahmood et al., 2013). Further these genotypes had fairly high dry matter accumulation which might have contributed for increase flower yield. Similar results were obtained in chrysanthemum (Negi and Raghava, 1985) and in marigold (Arora and Singh, 1980) and in gerbera (Nair and Mehedi, 2004). Higher yield might be due to increase in morphological parameters like plant height, number of leaves and leaf area which might have contributed in production of more photosynthates resulting in greater accumulation of dry matter which in turn leads to production of more number of flowers per plant (Ramzan et al., 2014). 
Table 02. Performance of 32 chrysanthemum cultivars on days to flower bud initiation, days to first petal spread, days to final bloom, number of flower bud/plant, number of flower/branch $(20 \mathrm{~cm})$ and number of flower/plant ${ }^{Y}$

\begin{tabular}{|c|c|c|c|c|c|c|c|c|c|c|c|c|}
\hline \multirow{2}{*}{$\frac{\text { Variety }^{\mathrm{x}}}{\mathrm{V}_{1}}$} & \multicolumn{2}{|c|}{$\begin{array}{l}\text { Days to flower } \\
\text { bud initiation }\end{array}$} & \multicolumn{2}{|c|}{$\begin{array}{l}\text { Days to first } \\
\text { petal spread }\end{array}$} & \multicolumn{2}{|c|}{$\begin{array}{l}\text { Days to } \\
\text { final } \\
\text { bloom }\end{array}$} & \multicolumn{2}{|c|}{$\begin{array}{c}\text { No. of flower } \\
\text { bud/plant at } \\
50 \text { DAT }\end{array}$} & \multicolumn{2}{|c|}{$\begin{array}{c}\text { No. of flower } \\
\text { /branch } \\
(20 \mathrm{~cm})\end{array}$} & \multicolumn{2}{|c|}{$\begin{array}{l}\text { No. of flower } \\
\text { /plant }\end{array}$} \\
\hline & 49.3 & $\mathrm{~b}$ & 66.6 & de & 77.2 & $\mathrm{a}$ & 11.7 & $\mathrm{x}$ & 1.0 & $\mathrm{k}$ & 10.3 & $t$ \\
\hline $\mathrm{V}_{2}$ & 38.8 & c & 58.7 & $\mathrm{kl}$ & 73.5 & $d$ & 4.3 & $\mathbf{y}$ & 1.0 & $\mathrm{k}$ & 4.3 & $\mathrm{v}$ \\
\hline$V_{3}$ & 17.8 & $\mathrm{r}$ & 39.5 & $\mathrm{~V}$ & 59.9 & o & 21.4 & $\mathrm{u}$ & 2.8 & i & 20.3 & $q$ \\
\hline$V_{4}$ & 34.4 & de & 71.6 & $\mathrm{a}$ & 77.5 & $\mathrm{a}$ & 24.3 & $\mathrm{~S}$ & 2.8 & $\mathrm{i}$ & 22.6 & $\mathrm{p}$ \\
\hline$V_{5}$ & 31.7 & $\mathrm{f}$ & 55.3 & 0 & 68.7 & jk & 47.5 & hi & 5.1 & $\mathrm{e}$ & 46.7 & $\mathrm{f}$ \\
\hline $\mathrm{V}_{6}$ & 26.5 & $\operatorname{lm}$ & 44.0 & $\mathrm{t}$ & 52.8 & $r$ & 55.5 & $\mathrm{f}$ & 8.5 & b & 54.7 & $d$ \\
\hline$V_{7}$ & 24.8 & $\mathrm{n}$ & 52.7 & $\mathrm{pq}$ & 64.5 & $\mathrm{~m}$ & 46.8 & $\mathrm{i}$ & 6.8 & $d$ & 45.6 & g \\
\hline $\mathrm{V}_{8}$ & 33.7 & $\mathrm{e}$ & 58.3 & $\operatorname{lm}$ & 70.3 & hi & 70.2 & c & 7.9 & c & 67.6 & c \\
\hline $\mathrm{V}_{9}$ & 52.7 & $\mathrm{a}$ & 67.4 & $\mathrm{~cd}$ & 76.7 & $\mathrm{a}$ & 22.5 & $\mathrm{t}$ & 2.8 & $\mathrm{i}$ & 20.3 & $q$ \\
\hline$V_{10}$ & 29.3 & gh & 69.5 & $\mathrm{~b}$ & 77.3 & $a$ & 38.1 & 1 & 1.0 & $\mathrm{k}$ & 36.3 & j \\
\hline $\mathrm{V}_{11}$ & 27.6 & $\mathrm{jk}$ & 56.6 & $\mathrm{n}$ & 72.6 & e & 31.4 & $\mathrm{p}$ & 6.5 & $\mathrm{~d}$ & 29.3 & $\mathrm{~m}$ \\
\hline $\mathrm{V}_{12}$ & 32.5 & $\mathrm{f}$ & 62.7 & $\mathrm{f}$ & 72.4 & ef & 35.3 & $\mathrm{~m}$ & 3.0 & hi & 30.7 & $\mathrm{k}$ \\
\hline$V_{13}$ & 23.8 & 0 & 62.5 & fg & 74.5 & bc & 22.8 & $\mathrm{t}$ & 3.8 & $\mathrm{f}$ & 20.5 & $\mathrm{q}$ \\
\hline $\mathrm{V}_{14}$ & 29.3 & gh & 57.5 & $\mathrm{~m}$ & 71.5 & $\mathrm{fg}$ & 33.2 & $\mathrm{n}$ & 3.5 & $\mathrm{fg}$ & 30.3 & $\mathrm{kl}$ \\
\hline $\mathrm{V}_{15}$ & 28.2 & $\mathrm{ij}$ & 60.2 & $\mathrm{ij}$ & 74.6 & bc & 199.0 & $\mathrm{a}$ & 9.4 & $a$ & 194.6 & $\mathrm{a}$ \\
\hline$V_{16}$ & 22.7 & $\mathrm{p}$ & 48.0 & $r$ & 73.8 & $\mathrm{~cd}$ & 58.0 & d & 1.8 & $\mathrm{j}$ & 55.5 & $\mathrm{~d}$ \\
\hline$V_{17}$ & 23.9 & no & 55.4 & 0 & 69.2 & j & 95.0 & $\mathrm{~b}$ & 3.6 & $\mathrm{f}$ & 92.0 & $\mathrm{~b}$ \\
\hline $\mathrm{V}_{18}$ & 24.4 & no & 46.0 & $\mathrm{~s}$ & 54.6 & $q$ & 48.2 & $\mathrm{~h}$ & 3.1 & ghi & 45.9 & g \\
\hline$V_{19}$ & 28.8 & hi & 53.6 & $\mathrm{p}$ & 69.2 & j & 47.6 & $\mathrm{~h}$ & 3.4 & fgh & 45.4 & $\begin{array}{l}0 \\
\mathrm{~g}\end{array}$ \\
\hline $\mathrm{V}_{20}$ & 28.4 & $\mathrm{ij}$ & 42.2 & $\mathrm{u}$ & 56.6 & $\mathrm{p}$ & 32.6 & $\mathrm{n}$ & 3.0 & hi & 29.7 & $\mathrm{~lm}$ \\
\hline $\mathrm{V}_{21}$ & 31.9 & f & 52.8 & $\mathrm{pq}$ & 65.2 & $\mathrm{~m}$ & 26.6 & $\mathrm{r}$ & 1.0 & $\mathrm{k}$ & 26.7 & o \\
\hline$V_{22}$ & 28.0 & $\mathrm{ijk}$ & 67.6 & c & 74.4 & bc & 30.3 & $q$ & 3.0 & hi & 27.6 & $\mathrm{n}$ \\
\hline $\mathrm{V}_{23}$ & 26.6 & $\operatorname{lm}$ & 61.6 & gh & 74.3 & bcd & 56.4 & $\mathrm{e}$ & 3.0 & hi & 55.3 & $d$ \\
\hline$V_{24}$ & 25.8 & $\mathrm{~m}$ & 55.7 & no & 67.7 & l & 44.8 & j & 1.0 & $\mathrm{k}$ & 42.4 & $\mathrm{~h}$ \\
\hline $\mathrm{V}_{25}$ & 28.5 & hi & 59.4 & $\mathrm{jk}$ & 68.0 & $\mathrm{kl}$ & 31.8 & op & 3.5 & fg & 29.7 & $\operatorname{lm}$ \\
\hline $\mathrm{V}_{26}$ & 34.8 & $\mathrm{~d}$ & 60.9 & hi & 71.8 & efg & 54.7 & g & 3.0 & hi & 51.7 & $\mathrm{e}$ \\
\hline $\mathrm{V}_{27}$ & 34.3 & de & 65.7 & $\mathrm{e}$ & 74.9 & $\mathrm{~b}$ & 39.6 & $\mathrm{k}$ & 2.0 & $\mathrm{j}$ & 38.5 & $\mathrm{i}$ \\
\hline $\mathrm{V}_{28}$ & 19.1 & $\mathrm{q}$ & 52.4 & $\mathrm{q}$ & 62.0 & $\mathrm{n}$ & 48.2 & $\mathrm{~h}$ & 2.9 & $\mathrm{i}$ & 45.8 & g \\
\hline$V_{29}$ & 21.2 & $\mathrm{kl}$ & 59.3 & $\mathrm{jk}$ & 71.0 & gh & 19.5 & $\mathrm{v}$ & 1.8 & j & 17.5 & $r$ \\
\hline $\mathrm{V}_{30}$ & 29.3 & gh & 61.8 & $\mathrm{~g}$ & 76.7 & $\mathrm{a}$ & 17.7 & $\mathrm{w}$ & 1.0 & $\mathrm{k}$ & 14.5 & s \\
\hline$V_{31}$ & 30.2 & g & 57.7 & $\mathrm{~m}$ & 69.5 & $\mathrm{ij}$ & 32.5 & no & 1.0 & $\mathrm{k}$ & 30.5 & $\mathrm{kl}$ \\
\hline $\mathrm{V}_{32}$ & 30.0 & $\mathrm{~g}$ & 55.7 & 0 & 69.4 & j & 11.8 & $\mathrm{x}$ & 3.0 & hi & 9.5 & $\mathrm{u}$ \\
\hline$C V \%$ & 1.8 & & 1.0 & & 0.8 & & 1.1 & & 8.1 & & 1.2 & \\
\hline$L S D_{(0.05)}$ & 0.9 & & 0.9 & & 0.9 & & 0.8 & & 0.4 & & 0.8 & \\
\hline
\end{tabular}

XChrysanthemum cultivars; YIn a column means having similar letter (s) are statistically identical and those having dissimilar letter (s) differ significantly as per 0.05 level of probability

Bud diameter at initiation stage: Bud diameter of chrysanthemum cultivars varied significantly at initiation stage. Maximum bud diameter was obtained from $V_{4}$ and $V_{10}(7.1 \mathrm{~mm})$ cultivars whereas minimum was obtained from $V_{19}$ and $V_{24}(1.7 \mathrm{~mm})$ cultivars at initiation stage (Table 03). This result showed that $\mathrm{V}_{4}$ (Chandramukhi) and $\mathrm{V}_{10}$ (Sunny Yellow) provided maximum bud diameter at initiation stage.

Bud diameter at mature stage: Significant variation was observed among chrysanthemum cultivars in terms of bud diameter at mature stage. Maximum bud diameter was found from $\mathrm{V}_{1}(19.1 \mathrm{~mm})$ whereas minimum was found from $V_{24}(6.3 \mathrm{~mm})$ which was statistically identical with $\mathrm{V}_{15}(6.5 \mathrm{~mm})$ and $\mathrm{V}_{8}(6.9 \mathrm{~mm})$ (Table 03). The findings referred that $\mathrm{V}_{1}$ (Crimson Tide) provided maximum bud diameter at mature stage. Small sized flowers are produced due to the less number of petals in its flower bud and large sized flowers are produced due to more number of petals in flower bud. Similar findings were found in carnation by (Maitra and Roychowdhury, 2014) 
Flower head diameter: Flower head diameter showed significant variation among the chrysanthemum cultivars after blooming. Maximum flower diameter was recorded from $V_{1}(17.6 \mathrm{~cm})$ while minimum from $V_{14}(2.8 \mathrm{~cm})$ which was statistically identical with $V_{15}$ (2.9) (Table 03). This result indicated that $\mathrm{V}_{1}$ (Crimson Tide) cultivar produced maximum flower diameter. Flower diameter of chrysanthemum ranged from 8.0 to $12.4 \mathrm{~cm}$ (Kunigunda, 2004) whereas 1.9 to $15.4 \mathrm{~cm}$ (Wesenberg et al., 1964) and 2.5 to $7.8 \mathrm{~cm}$ (Ara et al., 2012-13). The maximum diameter of 'Crimson Tide' might be due to inherent character of individual cultivars. Similar variations have been reported previously in Chrysanthemum (Kanamadi and Patil, 1993 and Rajashekaran et al., 1985), in Gerbera (Mahmood et al., 2013).

Stalk length: Significant variation was recorded for stalk length among chrysanthemum cultivars. The longest stalk of chrysanthemum flower was found from $V_{1}(20.1 \mathrm{~cm})$ which was statistically identical with $V_{13}(19.8 \mathrm{~cm})$ and $V_{2}(19.7 \mathrm{~cm})$ while the shortest was found from $V_{11}(4.4 \mathrm{~cm})$ which was statistically identical with $\mathrm{V}_{5}(4.5 \mathrm{~cm}), \mathrm{V}_{6}(4.7 \mathrm{~cm}), \mathrm{V}_{9}(4.7 \mathrm{~cm}), \mathrm{V}_{19}(4.8 \mathrm{~cm}), \mathrm{V}_{24}(4.8 \mathrm{~cm}), \mathrm{V}_{23}(4.9 \mathrm{~cm})$ and $V_{26}(5.0 \mathrm{~cm})$ (Table 03). The result indicated that $\mathrm{V}_{1}$ (Crimson Tide) cultivar performed as the longest stalk length producing cultivar. This difference in stalk length could be attributed to a genetic factor which is expected to vary among cultivars. Similar findings were found in gerbera (Sarkar and Ghimaray, 2004). It was observed that the cultivars with higher plant height produced the longer flower stalk as compared to cultivars with smaller plant heights. Similar findings were reported in rose (Ramzan et al., 2014; Mantur et al., 2005; Fascella and Zizzo, 2005) and in snapdragon (Shafique et al., 2011).

Flower durability (days to $\mathbf{5 0 \%}$ flower senescence): Chrysanthemum cultivars showed significant variation in terms of days taken to $50 \%$ flower senescence. Late flower senescence was recorded in $V_{21}$ (20.7 days) which was statistically identical with $V_{11}$ (19.8 days) while early flower senescence was observed in $V_{24}$ (11.3 days) (Table 03). The result indicated that $V_{21}$ (First Light) and $V_{11}$ (Lavender Mum) cultivars performed best in case of flower durability. It was found that durability of potted chrysanthemum varied greatly according to the cultivars. Generally being ethylene non-sensitive flower the difference in days taken to flower senescence may be due to varietal characteristics of different chrysanthemum cultivars. Similar findings were found in rose (Tabassum et al., 2002) and in gerbera (Nair and Mehedi, 2004).

Table 03. Performance of 32 chrysanthemum cultivars on bud diameter at initiation stage and mature stage, flower head diameter, stalk length and days to $50 \%$ flower senescence

\begin{tabular}{|c|c|c|c|c|c|c|c|c|}
\hline Varietyx & $\begin{array}{l}\text { Bud diameter at } \\
\text { initiation stage } \\
(\mathrm{mm})\end{array}$ & $\begin{array}{r}\text { Bud dian } \\
\text { mature } \\
\text { (mn }\end{array}$ & $\begin{array}{l}\text { eter at } \\
\text { stage }\end{array}$ & $\begin{array}{r}\text { Flowe } \\
\text { diam } \\
\text { (c) }\end{array}$ & $\begin{array}{l}\text { head } \\
\text { eter } \\
\text { h) }\end{array}$ & $\begin{array}{l}\text { Stalk le } \\
\quad(\mathrm{cm}\end{array}$ & & $\begin{array}{c}\text { Days to } 50 \% \\
\text { flower senescence }\end{array}$ \\
\hline$V_{1}$ & $4.8 \mathrm{~d}$ & 19.1 & a & 17.6 & $\mathrm{a}$ & 20.1 & $\mathrm{a}$ & $13.9 \mathrm{jk}$ \\
\hline $\mathrm{V}_{2}$ & $4.6 \mathrm{de}$ & 18.1 & $b$ & 16.0 & $b$ & 19.7 & $\mathrm{a}$ & 13.7 \\
\hline$V_{3}$ & $2.8 \mathrm{kl}$ & 16.9 & c & 14.6 & c & 16.6 & de & 15.3 ghi \\
\hline $\mathrm{V}_{4}$ & $7.1 \quad \mathrm{a}$ & 16.0 & d & 13.6 & d & 16.1 & $\mathrm{e}$ & 16.3 def \\
\hline $\mathrm{V}_{5}$ & $1.9 \mathrm{mn}$ & 8.6 & $\mathrm{p}$ & 3.7 & $\mathrm{pq}$ & 4.5 & o & 15.9 defg \\
\hline $\mathrm{V}_{6}$ & $2.6 \mathrm{jk}$ & 8.9 & op & 4.7 & $\operatorname{lmn}$ & 4.7 & no & 15.8 efg \\
\hline $\mathrm{V}_{7}$ & 2.8 & 10.5 & $\operatorname{lm}$ & 4.9 & $\operatorname{lm}$ & 5.7 & $\operatorname{lm}$ & 17.8 \\
\hline $\mathrm{V}_{8}$ & 3.2 & 6.9 & $\mathrm{r}$ & 5.0 & 1 & 5.2 & $\mathrm{mn}$ & 17.7 \\
\hline $\mathrm{V}_{9}$ & $2.4 \mathrm{kl}$ & 11.9 & ij & 7.8 & $\mathrm{i}$ & 4.7 & no & 16.8 \\
\hline $\mathrm{V}_{10}$ & $7.1 \quad \mathrm{a}$ & 14.7 & $\mathrm{e}$ & 6.8 & $\mathrm{jk}$ & 16.8 & d & 18.3 \\
\hline $\mathrm{V}_{11}$ & $\mathrm{mn}$ & 10.0 & $\mathrm{mn}$ & 8.8 & $\mathrm{~g}$ & 4.4 & o & 19.8 \\
\hline $\mathrm{V}_{12}$ & 4.2 & 14.2 & $\mathrm{e}$ & 8.7 & $\mathrm{~g}$ & 19.0 & $\mathrm{~b}$ & 14.5 \\
\hline $\mathrm{V}_{13}$ & 4.4 & 18.0 & $\mathrm{~b}$ & 9.8 & $\mathrm{f}$ & 19.8 & $\mathrm{a}$ & 14.2 \\
\hline $\mathrm{V}_{14}$ & 2.9 & 12.6 & gh & 2.8 & $r$ & 7.5 & $\mathrm{jk}$ & 14.7 \\
\hline $\mathrm{V}_{15}$ & $3.0 \mathrm{j}$ & 6.5 & $r$ & 2.9 & $r$ & 11.6 & $\mathrm{~g}$ & 17.7 \\
\hline$V_{16}$ & $2.7 \mathrm{jk}$ & 11.6 & jk & 6.9 & j & 18.0 & c & 17.7 \\
\hline$V_{17}$ & 3.9 gh & 9.5 & no & 4.6 & $\mathrm{mn}$ & 9.7 & $\mathrm{~h}$ & $16.5 \mathrm{de}$ \\
\hline
\end{tabular}




\begin{tabular}{|c|c|c|c|c|c|c|c|c|c|c|}
\hline $\mathrm{V}_{18}$ & 2.1 & $\operatorname{lm}$ & 7.6 & $\mathrm{q}$ & 4.0 & $\mathrm{p}$ & 5.7 & $\operatorname{lm}$ & 17.8 & $\mathrm{~b}$ \\
\hline $\mathrm{V}_{19}$ & 1.7 & $\mathrm{n}$ & 7.7 & $\mathrm{q}$ & 3.9 & $\mathrm{p}$ & 4.8 & no & 17.7 & bc \\
\hline $\mathrm{V}_{20}$ & 1.9 & $\mathrm{mn}$ & 8.7 & $\mathrm{p}$ & 4.1 & op & 6.9 & $\mathrm{k}$ & 18.4 & $\mathrm{~b}$ \\
\hline$V_{21}$ & 2.1 & $\operatorname{lm}$ & 8.9 & op & 3.8 & $\mathrm{p}$ & 8.3 & $\mathrm{i}$ & 20.7 & $\mathrm{a}$ \\
\hline$V_{22}$ & 2.9 & $\mathrm{j}$ & 8.7 & $\mathrm{p}$ & 4.7 & $\operatorname{lmn}$ & 6.0 & 1 & 14.4 & ijk \\
\hline $\mathrm{V}_{23}$ & 2.0 & $\operatorname{lm}$ & 7.5 & $\mathrm{q}$ & 4.9 & $\operatorname{lm}$ & 4.9 & no & 16.7 & de \\
\hline$V_{24}$ & 1.7 & $\mathrm{n}$ & 6.3 & r & 3.3 & $q$ & 4.8 & no & 11.3 & 1 \\
\hline $\mathrm{V}_{25}$ & 6.7 & b & 13.0 & $\mathrm{fg}$ & 6.6 & $\mathrm{jk}$ & 7.6 & $\mathrm{j}$ & 15.9 & efg \\
\hline$V_{26}$ & 5.2 & $c$ & 13.6 & $\mathrm{f}$ & 4.4 & no & 5.0 & no & 15.8 & efg \\
\hline$V_{27}$ & 6.6 & $\mathrm{~b}$ & 13.3 & $\mathrm{f}$ & 6.4 & $\mathrm{k}$ & 11.6 & $\mathrm{~g}$ & 13.7 & $\mathrm{k}$ \\
\hline$V_{28}$ & 2.1 & $\operatorname{lm}$ & 11.0 & $\mathrm{kl}$ & 6.7 & $\mathrm{jk}$ & 5.7 & $\operatorname{lm}$ & 18.3 & $\mathrm{~b}$ \\
\hline$V_{29}$ & 4.6 & de & 12.3 & hi & 8.1 & hi & 7.8 & $\mathrm{ij}$ & 15.5 & fgh \\
\hline$V_{30}$ & 3.8 & hi & 11.4 & $\mathrm{jk}$ & 8.2 & $\mathrm{~h}$ & 7.9 & ij & 16.0 & defg \\
\hline $\mathrm{V}_{31}$ & 4.4 & ef & 13.3 & f & 7.9 & hi & 13.5 & $\mathrm{f}$ & 13.7 & $\mathrm{k}$ \\
\hline$V_{32}$ & 3.9 & gh & 15.8 & $\mathrm{~d}$ & 11.3 & $\mathrm{e}$ & 17.7 & $\mathrm{C}$ & 14.5 & ijk \\
\hline CV\% & 6.1 & & 3.0 & & 3.5 & & 3.9 & & 3.5 & \\
\hline$L S D_{(0.05)}$ & 0.4 & & 0.6 & & 0.4 & & 0.6 & & 0.9 & \\
\hline
\end{tabular}

XChrysanthemum cultivars; YIn a column means having similar letter (s) are statistically identical and those having dissimilar letter (s) differ significantly as per 0.05 level of probability

\section{Conclusion}

Chrysanthemum cultivars showed wide range of variations in their growth and flowering characteristics. Maximum number of flower was found in $V_{15}(9.4 / 20 \mathrm{~cm}$ branch and 194.6/plant). Large flower $\left(17.6 \mathrm{~cm}\right.$ flower head diameter) with longest stalk $(20.1 \mathrm{~cm})$ was found in $V_{1}$. On the other hand, late flower senescence from the plant was recorded in $V_{21}$ (20.7 days). Breeders can easily select the desirable characters from this wide range of variation for the development of the chrysanthemum flowers.

\section{Acknowledgements}

Authors are highly grateful to those peoples and organizations who were help to collect the cultivars more especially Horticulture farm, Sher-e-Bangla Agricultural University, Dhaka; Krishibid Upokorn Nursery, Agargaon, Dhaka and Barisal Nursery, Savar, Dhaka, Bngladesh.

\section{References}

[1]. Arora, J. S., and Singh, J. (1980). Performance of marigold cultivars under North Indian conditions. In National Seminar on Production Technology for Commercial Flower Crops, pp. 8182.

[2]. Ahsan, M. K., Mehraj, H., Hussain, M. S., Rahman, M. M. and Jamal Uddin, AFM. (2014). Study on growth and yield of three promising strawberry cultivars in Bangladesh. Int. J. Bus. Soc. Sci. Res., 1(3): 205-208.

[3]. Ara, K. A., Sharifuzzaman, S. M. and Khan, F. N. (2012-2013). Collection and evaluation of chrysanthemum genotypes. BARI annual report, 814-817.

[4]. Barbosa, J. G. 2003. Crisântemos: produção de mudas, cultivo para corte de flor, cultivo em vaso, cultivo hidropônico . Viçosa: Aprenda Fácil 200: 179-215.

[5]. BARI. (2011). Krishi projukti hatboi (Handbook of Agro-technology), $2^{\text {nd }}$ part, $5^{\text {th }}$ edition. Bangladesh Agricultural Research Institute, Gazipur-1701, Bangladesh, pp: 217-222.

[6]. Barigidad, H. and Patil, A. A. (1992), Relative performance of chrysanthemum cultivars under transistional tract of karnataka. J. Agric. Sci. 10(1): 98-101.

[7]. Baskaran, V., Jayanthi, R., Janakiram, T. and Abirami, K. (2010). Evaluation of post-harvest quality of some cultivars of chrysanthemum. Journal of Horticultural Sciences 5(1): 81-83. 
[8]. Biswas, M., Sarkar, D. R., Asif, M. I., Sikder, R. K., Mehraj, H. and Jamal Uddin, A. F. M. (2014). Comparison of growth and yield characteristics of BARI tomato varieties. J. Biosci. Agric. Res. 3(1): $1-7$.

[9]. Chandragiri, R., Janakiram, T. and Srinivas, M. (2004). Performance of exotic Chrysanthemum varieties under greenhouse. Proceedings of National Symposium on Recent Trends and Future Strategies in Ornamental Horticulture. Univ. Agric. Sci., Dharwad, Karnataka (India), pp. 43-48.

[10]. Charles, G. (1995). Floriculture Design and Merchandising. Delmar Publisher TM An International Publishing Company, Washington, DC., pp: 394-3996.

[11]. Chaugule, B. B. (1985). Studies on genetic variability in chrysanthemum (Chrysanthemum morrifolium). An M. Sc. (Agri) thesis, Mahatma Phule Agricultural University, Rahuri. India.

[12]. Chezhian, N., Thumburaj, S., Khader, T. M. Z., Ponnushwami, V., Sambandamurhi, S. and Rangaswamy, P., (1985). New varieties of horticultural crops released by Tamil Nadu Agricultural University. South Indian Hort., 33: 72-73.

[13]. Chowdhury, M. S. N., Hoque, F., Mehraj, H. and Jamal Uddin, A. F. M. (2015). Vegetative growth and yield performance of four chilli (Capsicum frutescens) cultivars. American-Eurasian J. Agric. \& Environ. Sci. 15(4): 514-517.

[14]. Fascella, G. and Zizzo, G. V. (2005). Effect of growing media on yield and quality of soilless cultivated rose. Acta Hort, (ISHS) 697: 43-47.

[15]. Gharge, C. P., Angadi, S. G. , Biradar, M. S. and More, S. A. (2009). Evaluation of standard carnation (Dianthus caryophyllus Linn.) cultivars under naturally ventilated polyhouse conditions. J. Orn. Hort. 12(4): 256-260.

[16]. Gomez, K. A. and Gomez, A. A. (1984). Statistical Procedures for Agricultural Research. 2nd edn. John Wiley and Sons. New York. p. 680.

[17]. Hamblin, J., Stefanova, K. and Angessa, T. T. (2014). Variation in chlorophyll content per unit leaf area in spring wheat and implications for selection in segregating material. PLoS ONE 9(3): e92529.

[18]. Hicklenton, P. R. (1985). Influence of different levels and timing of supplemental irradiation on pot chrysanthemum production. Hort Sci., 20: 374-376.

[19]. Hossain, S., Jolly, S. N., Parvin, S., Mehraj, H. and Jamal Uddin, A. F. M. (2015). Performance on growth and flowering of sixteen hybrid gerbera cultivars. Int. J. Busi. Soc. Sci. Res. 3(2): 87-92.

[20]. Hossan, M. J., Islam, M. S., Ahsan, M. K., Mehraj, H. and Jamal Uddin, A. F. M. (2013). Growth and yield performance of strawberry germplasm at Sher-e-Bangla Agricultural University. J. Expt. Biosci. 4(1): 1-8.

[21]. Howe, T. K. and Waters, W. E. (1991). Evaluation of marigold cultivars as bedding plants, spring and fall 1989. Proc. Florida State Hort. Soc. 103: 332-3 37.

[22]. Hussain, A. and Khan, M. A. (2004). Effect of growth regulators on stem cutting of Rosa bourboniana and Rosa gruss-an-teplitz. Int. J. Agric. Biol. 6: 931-932.

[23]. Islam, M. S., Mehraj, H., Roni, M. Z. K., Shahrin, S. and Jamal Uddin, A. F. M. (2013). Varietal Study of Anthurium (Anthurium andraeanum) as a Cut Flower in Bangladesh. J. Bangladesh Academy Sci. 37(1): 103-107.

[24]. Islam, M. S., Mehraj, H., Roni, M. Z. K., Ona, A. F. and Jamal Uddin, A. F. M. (2013a). Morphological Analysis of Heliconia spp: A Promising Cut flower in Bangladesh. Int. J. Sustain. Agril. Tech. 9(1): 126-128.

[25]. Jamal Uddin, A. F. M., Islam, M. S., Mehraj, H., Roni, M. Z. K. and Shahrin, S. (2013). An Evaluation of Some Japanese Lisianthus (Eustoma grandiflorum) Varieties grown in Bangladesh. The Agriculturist 11(1): 56-60.

[26]. Jamal Uddin, A. F. M., Mehraj, H., Taufique, T., Ona, A. F. and Parvin, S. (2014b). Foliar application of gibberellic acid on growth and flowering of gerbera cultivars. J. Biosci. Agric. Res. 2(1): 52-58.

[27]. Jamal Uddin, AFM, Taufique, T., Mayeda, U., Roni, M. Z. K. and Mehraj, H. (2014a). Yield performance and phytochemical screening of three asparagus varieties. Bangladesh Res. Pub. J. 10(2): 196-201.

[28]. Joshi, M., Verma, L. R. and Masu, M. M. (2010). Performance of different varieties of chrysanthemum in respect of growth, flowering and flower yield under north Gujarat condition. The Asian J. Hort. 4(2): 292-294.

[29]. Kanamadi, V. C. and Patil, A. A. (1993). Perofrmance of chrysanthemum varieties in the transitional tract of Karnataka. South Indian Hort. 41: 58-60. 
[30]. Kim, S. J., Lee, C. H., Kim, J. and Kim, K. S. (2014). Phylogenetic analysis of Korean native Chrysanthemum species based on morphological characteristics. Sci. Hort.,175: 278-289.

[31]. Kunigunda, A. (2004). Variability of different traits in several chrysanthemum cultivars. University of Agricultural Sciences and Veterinary Medicine (UASVM), Cluj-Napoca, Romania. Not. Bot. Hort. Agrobot., 32(1): 24-26.

[32]. Mahesh, K. (1996). Variability studies in carnation (Dianthus caryophyllus L.) An M. Sc.(Agri) thesis, University of Agricultural Sciences, Bangalore.

[33]. Mahmood, M. A., Ahmed, N. and Khan, M. S. A. (2013). Comparative evaluation of growth, yield and quality characteristics of various gerbera (Gerbera jamesonii L.) Cultivars under protected condition. J. Orn. Plants. 3(4): 235-241.

[34]. Maitra, S. and Roychowdhury, N. (2014). Performance of Different Carnation (Dianthus Caryophyllus L.) Cultivars Grown from Seed in the Plains of West Bengal, India. Int. J. Bioresour. Stress Manage., 5(2): 294-297.

[35]. Mantur, S. M., Bagali, A. N. and Patil, S. R. (2005). Influence of bending and pruning on different varieties of roses under naturally ventilated polyhouse. Karnataka J. Agric. Sci. 18(2): 474-477.

[36]. Mehraj, H., Chanda, T., Masum Billah, A. A., Jahan, F. N. and Jamal Uddin, A. F. M. (2014e). Morpho-physiological and flowering behavior of bougainvillea cultivars. Int. J. Sustain. Crop Prod. 9(3): 35-40.

[37]. Mehraj, H., Mutahera, S., Roni, M. Z. K., Nahiyan, A. S. M., and Jamal Uddin, A. F. M. (2014c). Performance assessment of twenty tomato varieties for summer cultivation in Bangladesh. J. Sci. Tech. Env. Info. 1(1): 45-53.

[38]. Mehraj, H., Shikha, K. J., Nusrat, A., Shiam, I. H. and Jamal Uddin, A. F. M. (2014d). Growth and flowering behaviour of dendrobium cultivars. J. Biosci. Agric. Res. 2(2): 90-95.

[39]. Mehraj, H., Tamima, M. H., Chowdhury, M. S. N., Ferdous, M. H. and Jamal Uddin, A. F. M. (2014a). Study on Morpho-physiological characteristics and yield performance of four chilli lines. J. Biosci. Agric. Res. 2(1): 1-7.

[40]. Mehraj, H., Taufique, T., Ona, A. F., Nusrat, A. and Jamal Uddin, A. F. M. (2014b). Performance of gerbera cultivars under different wavelengths of solar spectrum. J. Bangladesh Academy Sci. 38(1): 27-37.

[41]. Mishra, R. L. and Saini, H. C. (1997). Genotypic and phenotypic variability in dahlia (Dahlia variabilis). Indian J. Hort. 17: 148-152.

[42]. Mitra, M. and Pal, P. (2008). Performance of chrysanthemum x morifolium Ramat, c.v. Chandrama grown at chrysanthemum different level of planting density and stem maintained per plant. Natural Product Radiance 7(2): 146-149.

[43]. Moe, R. (1988). Effect of stock plant environment on lateral branching and rooting. Acta Hort. 226: 421-430.

[44]. Munikrishnappa, P. M., Patil, A. A., Patil, V. S., Patil, B. N., Channappagoudar, B. B. and Alloli, T. B. (2013). Studies on the growth and yield parameters of different genotypes of China aster (Callistephus chinensis Nees.). Karnataka J. Agric. Sci. 26(1).

[45]. Nahiyan, A. S. M., Momena, K., Mehraj, H., Shiam, I. H., Jamal Uddin, A. F. M and Rahman, L. 2014. Genetic diversity of sixteen tomato varieties grown at Sher-e-Bangla Agricultural University. Int. J. Bus. Soc. Sci. Res. 2(1): 39-44.

[46]. Nair, A. S. and Medhi, R. P. (2004). Performance of gerbera cultivars in the Bay Islands. Indian J. Hort. 59(3): 322-325.

[47]. Nair, S. A., and Shiva, K. N. (2003). Genetic variability, correlation and path coefficient analysis in gerbera. J. Orn. Hort. 6(3): 180-187.

[48]. Negi, S. S. and Raghava, S. P. S. (1985). Improvement of chrysanthemum and China aster through breeding. Annual Report for, Indian Institute of Horticultural Research, Bangalore.

[49]. Nadeem, M., Khan, M. A., Riaz, A. and Ahmad, R. (2011). Evaluation of growth and flowering potential of Rosa hybrida cultivars under Faisalabad climatic conditions. Pak. J. Agri. Sci., 48(4), 283-288.

[50]. Punetha, P., Rao, V. K. and Sharma, S. K. (2011). Evaluation of different chrysanthemum (Chrysanthemum moliforium) genotypes under mid hill condition of Gharwal Himalaya .The Indian J. Agric. Sci. 81(9).

[51]. Raghuvanshi, Ajay and Sharma, B. P. (2011). Varietal evaluation of french marigold (Tagetes patula linn.) under mid-hill zone of Himachal Pradesh. Prog. Agric. 11(1): 123-126. 
[52]. Rajashekaran, C. R., Shanmugavelu, K. G. and Natraj, N. S. (1985). New varieties of horticultural crops released by Tamil Nadu Agricultural University. South Indian Hort. 33: 70-71.

[53]. Ramzan, A., Hanif, M. and Tariq, S. (2014). Performance of Rosa hybrida cultivars under agro climatic condition of Islamabad, Pakistan. J. Agric. Res. 52(1).

[54]. Sarkar, I. and Ghimiray, T. S. (2004). Performance of gerbera under protected condition in hilly region of West Bengal. J. Orna. Hort. 7(3\&4): 230-234.

[55]. Shafique, M., Maqbool, M., Nawaz, M. A. and Ahmed, W. (2011). Performance of various snapdragon (Antirrhinum majus L.) cultivars as cut flower in Punjab, Pakistan. Pakistani. J. Bot. 43(2): 1003-10.

[56]. Shahrin, S., Roni, M. Z. K., Taufique, T., Mehraj, H. and Jamal Uddin, A. F. M. (2015). Study on flowering characteristics and categorization of rose cultivars for color, fragrance and usage. J. Biosci. Agric. Res. 3(02): 87-95.

[57]. Shiragur, M., Shirol, A. M., Reddy, B. S. and Kulkarni, B. S. (2004). Performance of standard Carnation (Dianthus caryophyllus L.) cultivars under protected cultivation for vegetative characters. J. Orn. Hort. 7(3-4): 212-216.

[58]. Tabassum, R. I., Ghaffoor, A., Waseem, K. and Nadeem, M. A. (2002). Evaluation of rose cultivars as cut flower production. Asian J. Plant Sci. 1: 668-669.

[59]. Tarannum, M. S, and Hemla, N. B. (2014). Performance of Carnation (Dianthus Csryophyllus L.) genotypes for qualitative and quantitative parameters to assess genetic variability among genotypes. American Int. J. Res. Form, Appl. and Nat. Sci. 5(1): 96-101.

[60]. Thomas, B. and Lekharani, C. (2008). Assessment of floral characters in commercial varieties of monopodial orchids. J. Orn. Hort., 11(1): 15-20.

[61]. Vikas, H. M., Patil, V. S., Agasimani, A. D. and Praveenkumar, D. A. (2011). Studies on genetic variability in dahlia (Dahlia variabilis L.) Department of Horticulture, Agriculture College, Dharwad, Karnataka, India. Indian .J. S. N. 2(2): 372-375.

[62]. Vrsek, I., Zidovec, V. Poje, M. and Coga, L. (2006). Influence of photoperiod and growth retardant on the growth and flowering of New England aster. Acta Hort. 711: 301-306.

[63]. Wilfret, G. J., Marousky, F. J. and Raulston. J. C. (1973). Evaluation of chrysanthemum cultivars as single plant pots for mass market sales. Proc. Fla. State Hort. Soc. 86: 391-395.

[64]. Zosiamliana, J. H., Reddy, G. S. N. and Rymbai, H. (2012). Growth, flowering and yield characters of some cultivars of China aster (Callistephus chinensis Ness.). College of Horticulture, APHU, Hyderabad. J. Nat. Prod. Plant Resour. 2(2): 302-305. 